\title{
PERTUMBUHAN BANDENG DI DUA TAMBAK SILVOFISHERY YANG BERBEDA UMUR DI KAWASAN MANGROVE PANTAI UTARA KABUPATEN REMBANG
}

\author{
Growth of Milkfish in Two Different Age Silvofishery Fishponds in Mangrove Area \\ in North Coast of Rembang Regency
}

\author{
Krisnawati $^{1} \&$ Erny Poedjirahajoe ${ }^{2}$ \\ ${ }^{1}$ Balai Penelitian dan Pengembangan Teknologi Hasil Hutan Bukan Kayu \\ Jalan Dharma Bhakti No 7 Langko Lingsar Lombok Barat 83371 \\ ${ }^{2}$ Fakultas Kehutanan Jurusan Konservasi Sumberdaya Hutan UGM \\ Jl. Agro No. 1, Bulaksumur, Universitas Gadjah Mada, Sleman, DIY 55281 \\ 'Email :yakrisnawati@yahoo.com
}

\begin{abstract}
Silvofishery agroforestry pattern is used in the implementation of social forestry program of mangrove forest region. Farmers may keep the fish, shrimp, crab or other commercial types to preserve mangrove forests. The purpose of this study was to determine the growth of milkfish in ponds created silvofishery year 1960 (A) and for the year 1970 (B). Method to determine the weight of growing milkfish ponds that any given observation cages as a plot with three replications. Laying the plot is on the leftright and center to represent the area of the pond embankment. The analysis used descriptive statistical analysis. The results obtained from this study is on the old farm pond A 47 year average growth of tentails milk: 869.33 grams and on farm B byage 37 the average weight per tentails milk: 866.11 grams. Difference in averages in the second increased milkfish ponds of 3.22 grams and includes result were small. This means that age does not affect the growth of milkfish ponds in the North Coastarea of mangrove Rembang regency.
\end{abstract}

Keywords: Silvofishery, weight milkfish, age ponds

\begin{abstract}
ABSTRAK
Silvofishery merupakan pola agroforestry yang digunakan dalam pelaksanaan program perhutanan sosial di kawasan hutan mangrove. Petani dapat memelihara ikan, udang, kepiting atau jenis komersial lainnya untuk memelihara hutan mangrove. Tujuan dari penelitian ini adalah mengetahui pertumbuhan bandeng pada tambak silvofishery tahun buat 1960 (A) dan tahun buat 1970 (B). Metode untuk mengetahui pertumbuhan berat bandeng yaitu setiap tambak diberi keramba jaring sebagai plot pengamatan dengan tiga kali ulangan. Peletakan plot berada di kiri-kanan dan tengah tambak agar mewakili luasan tambak. Analisis yang digunakan adalah analisis statistik deskriftif. Hasil yang diperoleh dari penelitian ini adalah pada tambak A dengan umur tambak 47 tahun pertumbuhan rata-rata sepuluh ekor bandeng yaitu 869,33gram dan pada tambak B dengan umur 37 tahun pertambahan berat rata-rata per sepuluh ekor bandeng yaitu 866,11 gram. Selisih rata - rata pertambahan berat bandeng di kedua tambak sebesar 3,22 gram dan termasuk hasil yang kecil. Artinya pertambahan berat rata - rata bandeng di kedua tambak yang berbeda umur sama, sehingga tidak mempengaruhi pertumbuhan bandeng di kawasan mangrove Pantai Utara Kabupaten Rembang.
\end{abstract}

Kata Kunci : Silvofishery, pertambahan berat bandeng, umur tambak.

\section{A. PENDAHULUAN}

Hutan mangrove dapat didefinisikan sebagai suatu hutan yang tumbuh di daerah pasang surut (terutama dipantai yang terlindung, laguna, sepanjang sungai dan muara sungai) yang tergenang pada saat pasang 
dan bebas pada saat surut yang komunitas tumbuhannya bertoleransi terhadap garam. (Kusmana, 2003). Fungsi hutan mangrove sebagai nursery ground sering dimanfaatkan untuk silvofishery. Ada 2 pola silvofishery yang sering dipergunakan oleh masyarakat untuk usaha pertambakan, yaitu: pola empang parit, tegakan mangrove dikelilingi oleh saluran air

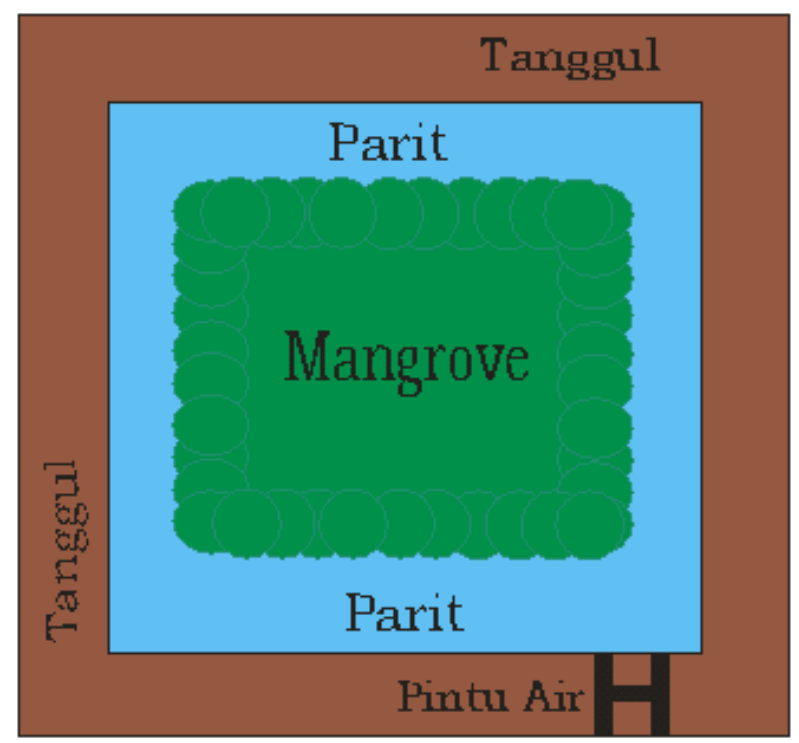

Gambar 1. Silvofishery pola empang parit Ficture 1. Patterns silvofishery pond ditch

Terkait dengan hutan mangrove dan perikanan, pentingnya areal mangrove sebagai habitat bagi jenis-jenis ikan ekonomis penting telah diakui secara luas. Namun perlu diingat bahwa habitat utama bagi organismeorganisme tersebut adalah teluk dangkal. Saluran pemasukannya dan saluran-saluran yang merupakan bagian yang tidak terpisahkan dari sistem mangrove.Kabupaten Rembangdi Pesisir Utara Pulau Jawamempunyai potensi sumber daya laut yang besar. Karakteristik masyarakat umumnya bermata pencaharian sebagai petani, petani tambak dan nelayan. Tambak yang diusahakan masih banyak menggunakan sistem konvensional daripada dengan sistem silvofishery. Petani tambak masih kurang informasi mengenai sistem silvofishery yang dapat diusahakan, yaitu dengan pola komplangan atau empang parit. dan bentuk sejajar dengan pematang tambak (Gambar 1), dan pola komplangan, pohon mangrove ditanam pada daerah yang terpisah dengan empang memelihara ikan atau udang, dimana diantara keduanya terdapat pintu air penghubung yang mengatur keluar masuknya air (Gambar 2) dalam (Mahayani, 2002).

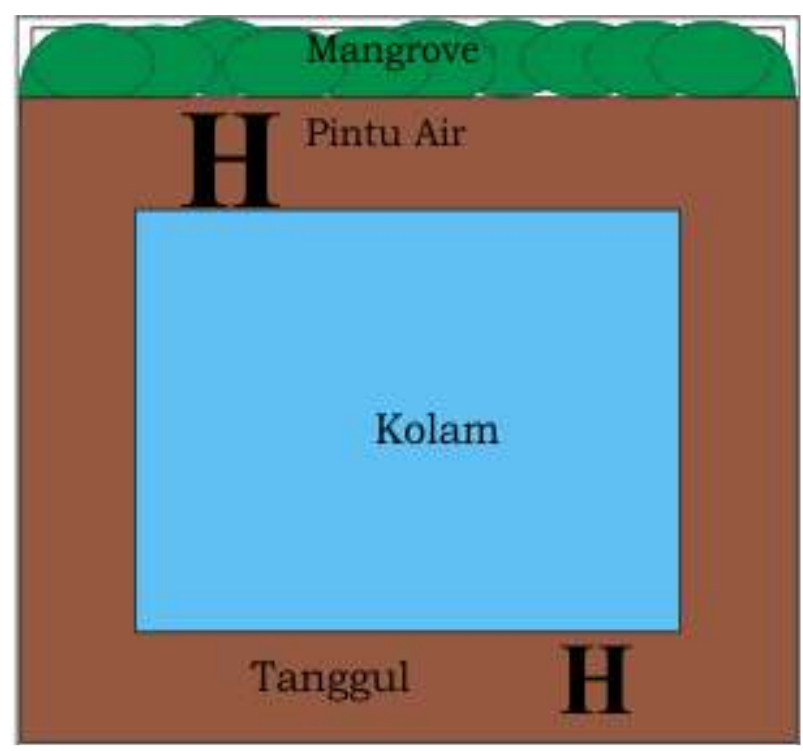

Gambar 2. Silvofishery pola komplangan Ficture 2. Patterns Silvofishery pond

Pertumbuhan ikan di tambak merupakan harapan bagi petani untuk mendapatkan hasil panen yang maksimal. Hasil panen yang dimaksud disini lebih ke berat, sehingga penelitian ini bertujuan untuk mengetahui pertumbuhan bandeng pada tambak silvofishery tahun buat 1960 dan tahun buat 1970.

\section{BAHAN DAN METODE}

Penelitian dilakukan di hutan mangrove pada tahun tanam 1971, kawasan rehabilitasi mangrove Pantai Utara di Desa Pasar Banggi, Kabupaten Rembang, Propinsi Jawa Tengah (Gambar 3). Pengambilan data dilaksanakan selama 3 bulan, yaitu pada bulan Maret sampai Mei 2007. Bahan dan alat yang dibutuhkan yaitu kawasan rehabilitasi hutan mangrove, 
tambak sistem silvofishery dengan pola komplangan tahun buat 1960 (A) dan tahun buat 1970 (B) (Gambar 4) dengan luas masing masing \pm 2 ha, peta lokasi penelitian, nener bandeng yang berusia 1 bulan, keramba jaring berukuran $1,30 \times 1,25 \times 1,25$ meter, timbangan

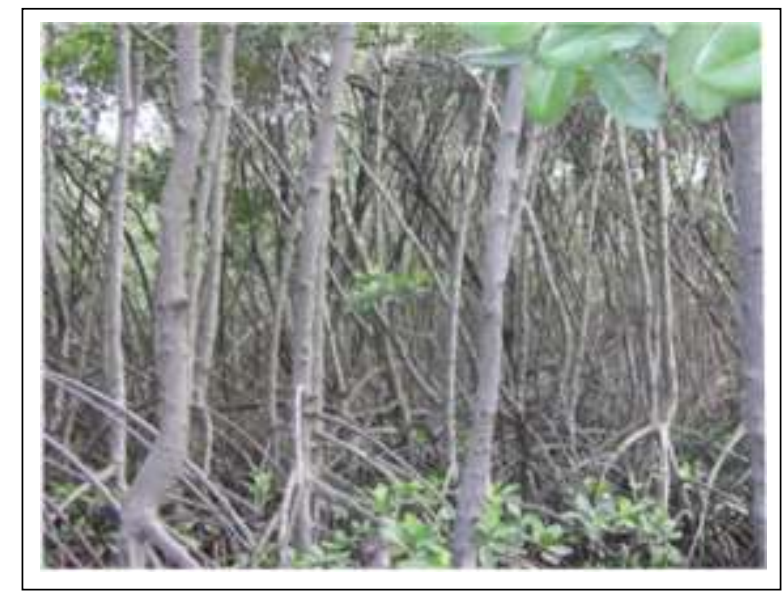

Gambar 3. Mangrove tahuntanam 1971

Picture 3. Mangrove planting year 1971

Data yang dikumpulkan untuk pertambahan berat bandeng dalam tambak A dan B yaitu pada setiap tambak yang telah dipasang keramba jaring diisi 10 nener bandeng berumur satu bulan yang sebelumnya dilakukan penimbangan berat, ini sebagai berat awal (Gambar 5 dan 6). Setiap hari, pagi dan sore ditaburi poor ikan (pellet) sebagai makanannya sebanyak kira-kira satu ons untuk setiap keramba. Satu minggu pertama jika ada

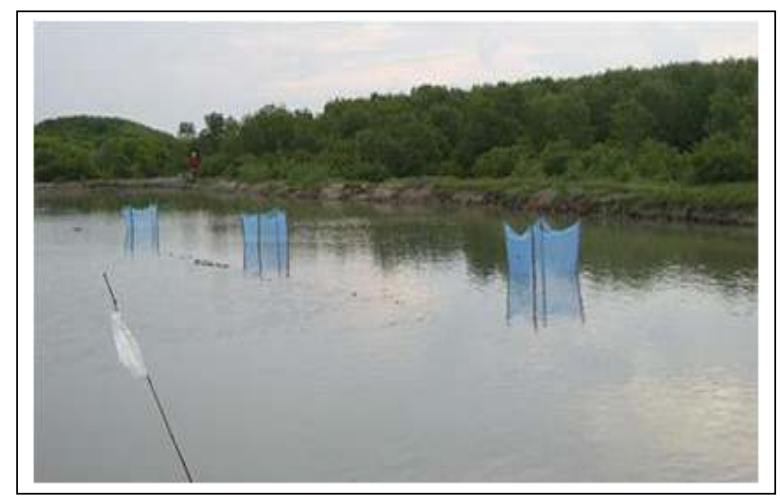

Gambar 5. Mangrove tahuntanam 1971 Picture 5. Mangrove planting year 1971 gantung, skopnet, ember, label nama, hagameter, patok kayu, Oxymeter, termometer stik, $\mathrm{pH}$ meter, salinity test digital, formalin $4 \%$, botol flakon, plankton net, pipet tetes, hemacytometer, roll meter, pita meter, kompas, tali, alat tulis dan dokumentasi.

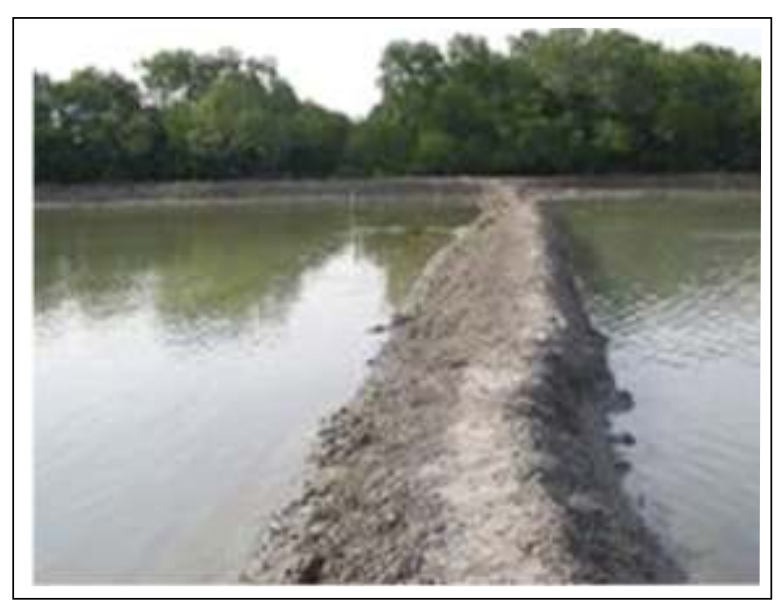

Gambar 4. Tambak tahun 1960 dan 1970 Picture 4. Pond in 1960 and 1970

yang mati dilakukan penyulaman, baru dilakukan penimbangan berat bandeng untuk minggu berikutnya (Ujang, 2002). Pengamatan persen hidup bandeng dilakukan setiap minggu sekali pada masing - masing tambak. Sehingga untuk persen hidup bandeng dihitung dengan menggunakan rumus :

\%hidup ikan $=\frac{\sum \text { jumlah ikan hidup panen }}{\sum \text { benih yang ditabur }}$

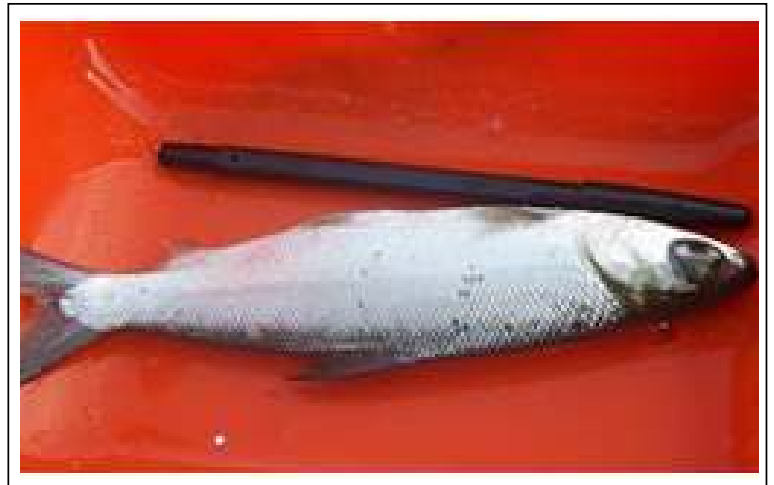

Gambar 6. Tambak tahun 1960 dan 1970 Picture 6. Pond in 1960 and 1970 
Data untuk komposisi dan kerapatan mangroveyaitu tinggi, lebar akar dan jenis vegetasi. Ukuran petak ukur (PU) yang digunakan 5 x 5 meter. Penempatan PU didasarkan pada 3 zona tumbuh, yaitu zona darat (distal zone), zona tengah (middle zone), dan zona depan (proximal zone). Pada setiap zona dibuat sebanyak 10 buah PU, sehingga jumlah PU keseluruhan 30 PU, lihat Gambar 3. Jenis vegetasi diidentifikasi menggunakan bantuan pustaka Panduan Pengenalan Mangrove di Indonesia (Noor, 2006) dan hasil pengambilan data vegetasi kemudian dihitung dengan rumus Indeks Diversitas Simpson (Kusmana, C. 1997).

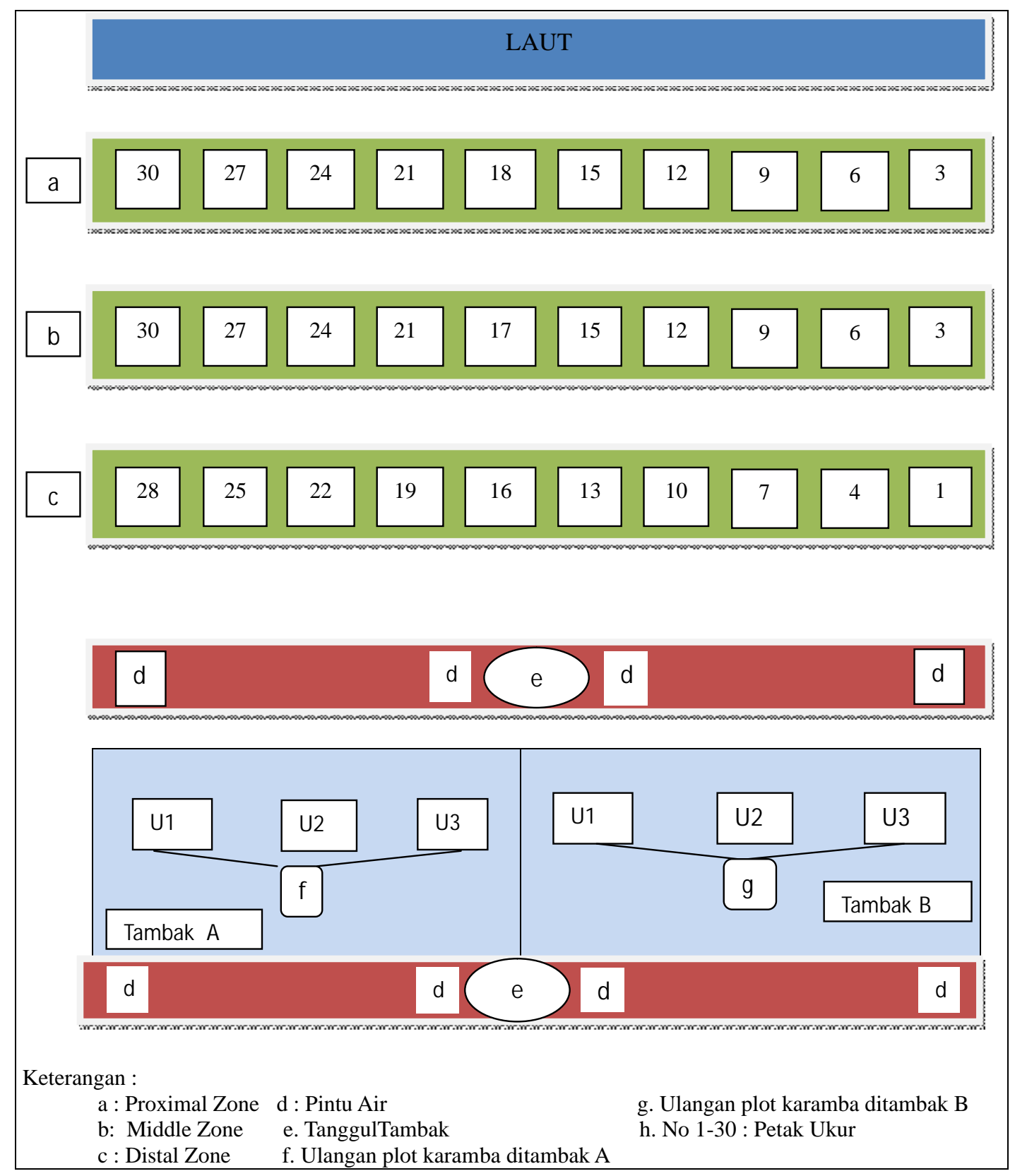

Gambar 7. Lay Out Penelitian

Figure 7. Lay Out Research 
Pengambilan data kepadatan plankton ada 2 kegiatan yaitu di lapangan dan di laboratorium. Masing-masing tempat dilakukan ulangan 10 kali, sehingga didapatkan 30 botol flakon sampel yang diberi label kemudian sampel diamati di laboratorium. Untuk mengetahui nama jenis plankton yang ditemui adalah dengan mencocokkan dengan gambar yang ada pada buku identifikasi plankton. Pengambilan data-data faktor lingkungan yaitu pengukuran oksigen terlarut (DO), pengukuran suhu, $\mathrm{pH}$ dan salinitas pada setiap lokasi dilakukan pengukuran ulangan sebanyak 10 kali. Kemudian dijumlahkan dan didapatkan hasil rata-rata. Analilis statistik yang digunakan dalam penelitian ini adalah statistik deskriptif.

\section{HASIL DAN PEMBAHASAN}

\section{A. Pertambahan Berat Bandeng 10 Ekor}

Hasil pengukuran yang dilakukan pada tambak A dan tambak B selama 3 bulan sesuai dengan masing-masing perlakuan diperoleh data pertambahan berat ikan bandeng, seperti tersaji pada Tabel 1 di bawah ini.

Tabel 1. Pertambahan berat bandeng

Table 1. Weight gain milkfish

\begin{tabular}{|c|c|c|c|c|c|}
\hline \multirow{2}{*}{$\begin{array}{l}\text { Tambak } \\
\text { (Pond) }\end{array}$} & \multirow{2}{*}{$\begin{array}{l}\text { Plot } \\
\text { (Plot) }\end{array}$} & \multirow{2}{*}{$\begin{array}{c}\text { Berat awal } \\
\text { (Initial weight) } \\
(\mathrm{gr})\end{array}$} & \multicolumn{3}{|c|}{$\begin{array}{c}\text { Bulan } \\
\text { (Month) }(\mathrm{gr})\end{array}$} \\
\hline & & & 1 & 2 & 3 \\
\hline \multirow{4}{*}{$\begin{array}{c}\text { Tambak A : } \\
\text { Bandeng }\end{array}$} & T1B1 & 300 & 1150 & 1750 & 2700 \\
\hline & T1B2 & 250 & 1025 & 1900 & 3100 \\
\hline & T1B3 & 275 & 1050 & 1775 & 2850 \\
\hline & $\begin{array}{l}\text { Rata-rata } \\
\text { (Average) }\end{array}$ & 275 & 1075 & 1808,33 & 2883,33 \\
\hline \multirow{4}{*}{$\begin{array}{c}\text { Tambak B : } \\
\text { Bandeng }\end{array}$} & T2B1 & 275 & 990 & 1675 & 2770 \\
\hline & T2B2 & 275 & 1200 & 1750 & 2825 \\
\hline & T2B3 & 300 & 1100 & 1755 & 3050 \\
\hline & $\begin{array}{l}\text { Rata-rata } \\
\text { (Average) }\end{array}$ & 283,33 & 1096,66 & 1727,77 & 2881,66 \\
\hline
\end{tabular}

Tabel 1 menunjukan rata-rata peningkatan berat bandeng 10 ekor selama 3 bulan pada tambak A dan B diperoleh dari berat hasil akhir dikurangi berat awal dibagi 3 (bulan). Tambak A diperoleh hasil rata-rata peningkatan berat bandeng 10 ekor selama 3 bulan sebesar 869,44 gram per bulan ( 2883,33 275 gram : 3) dan untuk tambak B diperoleh hasil rata-rata peningkatan berat bandeng 10 ekor selama 3 bulan adalah 866,11 gram per bulan (2881,66-283,33 gram : 3). Selisih ratarata peningkatan berat bandeng dikedua tambak sebesar 3,22 gram $(869,44-866,11$ gram). Hasil tersebut tergolong kecil. Umur tambak A, 47 tahun dengan umur tambak B, 37 tahun perbedaan selisih rata - rata pertambahan berat bandeng tidak begitu jauh. Sehingga tidak ada perbedaan yang nyata walaupun umur tambak berbeda 10 tahun.

Dibanding dengan penelitian sebelumnya, ditempat dan perlakuan yang sama oleh (Saputra, 2007) seperti terlihat pada Tabel 2. Rata-rata peningkatan berat bandeng antara tambak komplangan sebesar 886,11 gram/10 ekor (2.950-291,66 gram : 3) dan pada tambak konvensional sebesar 577,38 gram/10 ekor (2.050-316,66 gram : 2). Sehingga diperoleh hasil selisih sebesar 308,33 gram/10 ekor. 
Pada tambak silvofishery pola komplangan tahun 1975 terdapat selisih berat 2658,34 gram (2.950 - 291,66 gram)/10 ekor dibandingkan dengan hasil rata - rata di tambak A dan B sebesar 2603,33 gram (5206,66 gram : 2). Perbedaannya hanya 55,01 gram relatif tidak berarti. Namun jika dibandingkan dengan pola konvensional, dimana selisih berat bandeng sebesar 1733,34 gram (2.050 - 316,66 gram) ternyata tambak pola komplangan A dan B (2603,33 gram) jauh lebih baik yaitu sebesar 869,99 gram/10 ekor selama 3 bulan.

Perbedaan pertambahan berat bandeng yang berbeda menurut (Poedjirahajoe, 1998) disebabkan oleh desain pola yang berbeda, masukan bahan organik ataupun kandungan fitoplankton berbeda pula. Pada pola komplangan ketersediaan bahan organik dan suplai plankton lebih banyak. Tambak pola komplangan bersebelahan dengan mangrove sehingga seresah dari daun, buah atau ranting yang berguguran akan jatuh ke dalam tambak. Seresah-seresah ini akan melewati proses dekomposisi bahan organik oleh makrobentos dan pengurai yang ada. Hasil dari proses dekomposisi akan meningkatkan kandungan hara dalam lumpur. Meningkatnya kandungan hara akan memacu perkembangan plankton karena plankton akan berkembang baik pada tambak yang kandungan haranya tinggi.

Melimpahnya plankton akan menjadi sumber pakan tambahan bagi bandeng, pada penelitian ini membuktikan bahwa pertumbuhan dan pertambahan berat bandeng yang dibudidayakan pada tambak pola komplangan menjadi lebih baik jika dibanding dengan tambak pola konvensional.

Tabel 2. Pertumbuhan Berat Bandeng 10 Ekor Table 2. Growth Weight Milkfish 10 Tail

\begin{tabular}{ccrrcc}
\hline \multirow{2}{*}{$\begin{array}{c}\text { Jenis } \\
\text { Tambak }\end{array}$} & Ulangan & Berat & \multicolumn{3}{c}{ Bulan (gr) } \\
\cline { 2 - 6 } & & Awal (gr) & \multicolumn{1}{c}{1} & \multicolumn{1}{c}{2} & \multicolumn{1}{c}{3} \\
\hline Pola Komplangan & U1 & 300 & 1.100 & 1.500 & 2.900 \\
\hline 1975 & U2 & 300 & 1.050 & 2.050 & 3.250 \\
\hline & Rata-rata & $\mathbf{2 9 1 , 6 6}$ & $\mathbf{1 . 1 0 8 , 3 3}$ & $\mathbf{1 . 7 5 0}$ & 2.700 \\
\hline Pola Konvensional & U1 & 375 & 900 & 1.250 & 2.950 \\
\hline 1970 & U2 & 275 & 700 & 1.400 & 1.900 \\
\hline & U3 & 300 & 975 & 1.500 & 2.250 \\
\hline
\end{tabular}

Sumber : Saputra, 2007

\section{B. Persen Hidup Bandeng Pada Tambak A dan B}

Dalam kurun waktu pengamatan yaitu selama tiga bulan bandeng dapat hidup dengan cukup baik pada semua pola tambak yang diamati, hal ini terlihat dari banyaknya jumlah bandeng yang dipanen sama dengan banyaknya jumlah nener yang ditebar, seperti terlihat pada data hasil pengamatan pada Tabel 3 di bawah ini.
Bandeng pada tambak A dan tambak B tahun persen hidupnya $100 \%$, berarti bandeng dari awal sampai akhir penelitian hidup semua. Kondisi tambak yang terbilang tua, 47 tahun dan 37 tahun sudah stabil bagi keberlangsungan bandeng, jadi nener yang baru ditebar di tambak tidak membutuhkan waktu lama untuk beradaptasi, karena kondisi lingkungan tambah sudah stabil dan mendukung bagi perkembangan dan pertumbuhannya. 
Tabel 3. Persen hidup bandeng pada tambak A dan tambak B

Table 3. Percent of live milkfish in ponds and ponds $A B$

\begin{tabular}{|c|c|c|c|c|c|c|}
\hline \multirow{2}{*}{ Tambak A } & \multirow{2}{*}{ Plot } & \multirow{2}{*}{$\begin{array}{c}\text { Jumlah Awal } \\
\text { (ekor) }\end{array}$} & \multicolumn{3}{|c|}{ Bulan (ekor) } & \multirow[t]{2}{*}{$\%$} \\
\hline & & & 1 & 2 & 3 & \\
\hline \multirow[t]{4}{*}{ Bandeng } & T1B1 & 10 & 10 & 10 & 10 & \\
\hline & T1B2 & 10 & 10 & 10 & 10 & \\
\hline & T1B3 & 10 & 10 & 10 & 10 & \\
\hline & Rata-rata & 10 & 10 & 10 & 10 & 100 \\
\hline \multirow[t]{2}{*}{ Tambak B } & Plot & JumlahAwal & \multicolumn{3}{|c|}{ Bulan (ekor) } & $\%$ \\
\hline & & (ekor) & 1 & 2 & 3 & \\
\hline \multirow{4}{*}{ Bandeng } & T2B1 & 10 & 10 & 10 & 10 & \\
\hline & $\mathrm{T} 2 \mathrm{~B} 2$ & 10 & 10 & 10 & 10 & \\
\hline & T2B3 & 10 & 10 & 10 & 10 & \\
\hline & Rata-rata & 10 & 10 & 10 & 10 & 100 \\
\hline
\end{tabular}

\section{Faktor -Faktor Lingkungan}

Faktor lingkungan erat kaitannya dengan mahluk hidup, sehingga sangat berpengaruh bagi pertumbuhan dan perkembangan mahluk hidup termasuk bandeng, dalam penelitian ini terdapat beberapa faktor lingkungan yang diamati antara lain adalah suhu perairan, drajat keasaman air, salinitas air dan banyaknya oksigen terlarut dalam air. Data yang diperoleh dari penelitian ini tersaji pada Tabel 4 di bawah ini.

Tabel 4. Rata - rata faktor fisik lingkungan

Table 4. Averages physical factors of the environment

\begin{tabular}{lcccc}
\hline $\begin{array}{c}\text { Lokasi } \\
\text { (location) }\end{array}$ & $\begin{array}{c}\text { Suhu perairan } \\
\text { (water temperature) } \\
\left({ }^{\circ} \mathrm{C}\right)\end{array}$ & $\begin{array}{c}\text { Drajat Keasaman } \\
\text { (acidity) } \\
\mathrm{pH}\end{array}$ & $\begin{array}{c}\text { Salinitas } \\
\text { (salinity) } \\
(\mathrm{ppt})\end{array}$ & $\begin{array}{c}\text { Oksigen terlarut } \\
\text { (dissolved } \\
\text { oxygen })(\mathrm{ppm})\end{array}$ \\
\hline Mangrove tahun tanam 1971 & 30,83 & 6,66 & 9,37 & 4,70 \\
\hline Tambak A & 30,93 & 7,16 & 7,41 & 4,48 \\
\hline Tambak B & 31,18 & 7,50 & 7,20 & 4,51 \\
\hline
\end{tabular}

Suhu dibutuhkan oleh seluruh biota dan makhluk hidup di perairan terutama untuk proses fotosintesis dan respirasi. Suhu pada kawasan mangrove lebih rendah $\left(30,83{ }^{\circ} \mathrm{C}\right)$ daripada di kawasan tambak. Hal ini disebabkan sinar matahari yang masuk terhalang oleh adanya penutupan tajuk dari vegetasi. Berbeda dengan kawasan tambak yang merupakan daerah hamparan yang tanpa adanya naungan. Sehingga sinar matahari yang masuk ke permukaan tambah lebih banyak dan maksimal.
Hasil pengukuran drajat keasaman perairan dari ketiga lokasi hampir sama yaitu berkisar pH 6-7 (netral), menunjukan kondisi air dalam areal mangrove dan areal tambak tidak terlalu asam atau basa. Besarnya nilai $\mathrm{pH}$ dalam suatu perairan dapat dijadikan indikator adanya keseimbangan unsur-unsur kimia dan unsur-unsur hara yang bermanfaat bagi kehidupan vegetasi akuatik (Poedjirahajoe, 2005). Derajat keasaman air juga mempunyai peranan penting bagi kehidupan ikan dan fauna lain yang hidup di perairan tersebut. 
Salinitas air yang rendah dipengaruhi oleh aliran sungai yang masuk ke mangrove yang berfungsi sebagai penetralisir. Selain itu salinitas air dipengaruhi oleh cuaca setempat dan faktor edafik (Kusmana O. d., 2008). Salinitas yang tinggi pada areal mangrove tahun tanam 1971 dimungkinkan karena areal mangrove letaknya dekat dengan laut. Sedangkan tambak A dan B letaknya lebih jauh dan terhalang oleh areal mangrove, sehingga terpengaruh salinitas air laut. Kawasan tambak membutuhkan salinitas sedang karena salinitas yang tinggi akan menyebabkan tekanan osmotik yang tinggi sehingga dapat menyebabkan kematian bagi ikan (Kehutanan, 1997).

Kandungan oksigen terlarut tertinggi pada mangrove tahun tanam 1971. Hal ini diindikasikan karena kerapatan vegetasi yang tinggi dan banyaknya seresah yang jatuh dari vegetasi yang ada pada areal mangrove. Sehingga menambah unsur hara yang ada pada kawasan mangrove. Kadar oksigen terlarut yang tinggi sangat diperlukan bagi mangrove tumbuh pada perairan yang berlumpur tebal dan anerob. Kondisi tersebut mengakibatkan tumbuhan mangrove mengembangkan perakaran khusus untuk beradaptasi dengan lingkungannya. Oksigen terlarut yang ada akan digunakan oleh makhluk hidup di hutan mangrove untuk proses metabolisme di dalam tubuhnya, sehingga menurunnya kandungan oksigen terlarut dapat mempengaruhi kehidupan biota perairan yang ada.

\section{Kepadatan Plankton}

Kepadatan plankton yang tertinggi terdapat pada areal mangrove tahun tanam 1971 dibandingkan di tambak A dan B, hal ini dikarenakan jumlah individu plankton yang ada di areal mangrove cukup banyak dan untuk proses fotosintesis khususnya fitoplankton dapat masuk dengan optimal.

Sedangkan tingkat keanekaragaman suatu jenis atau yang disebut indeks diversitas ditentukan dengan rumus ID $=1-\lambda$, membuktikan bahwa Indeks diversitas plankton pada mangrove tahun tanam 1971 merupakan yang terbesar yaitu 0,95 dan terendah di tambak A sebesar 0,88 . Meningkatnya kandungan unsur hara dalam tanah akan meningkatkan diversitas plankton yang merupakan pakan alami bagi nekton seperti ikan.

\section{Kepadatan Plankton}

Keberadaan plankton sangat dibutuhkan oleh ikan sebagai salah satu sumber pakan alami. Pada penelitian ini juga dilakukan pengamatan seberapa jauh tingkat kepadatan plankton yang terdapat dalam masing-masing tambak yang diamati. Apakah perbedaan lokasi tambah akan mempengaruhi jumlah plankton atau tidak. Hasil pengamatan kepadatan plankton dapat dilihat pada Gambar 8 di bawah ini.

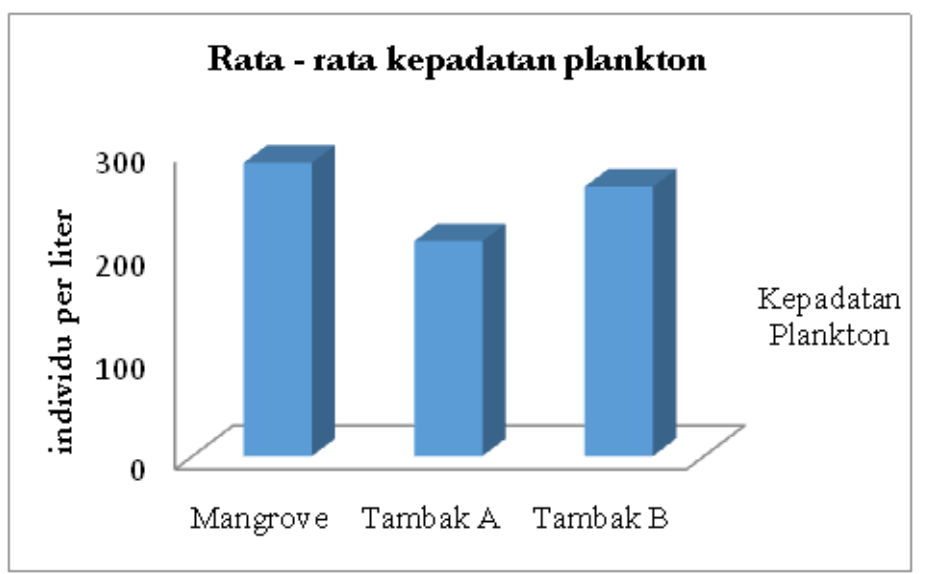

Gambar 8. Grafik rata-rata dari kepadatan plankton Figure 8. Graph of the average of the density of plankton 
Kepadatan plankton yang tertinggi terdapat pada areal mangrove tahun tanam 1971 dibandingkan di tambak A dan B, hal ini dikarenakan jumlah individu plankton yang banyak dan untuk proses fotosintesis khususnya fitoplankton dapat masuk dengan optimal.

Sedangkan untuk indeks diversitas seperti yang terlihat pada Gambar 9 terendah terjadi pada tambak A ini karena rendahnya diversitas plankton, tambak tergolong tua dengan umur 47 tahun kondisi lumpurnya cukup tebal mengakibatkan kondisi menjadi anoksikdaripada tambak B dan areal mangrove.

Perbedaan kepadatan plankton ini disebabkan oleh pengaruh pasangsurut air laut yang membawa plankton dan pengaruh kondisi lingkungan di tambak. Kepadatan plankton merupakan indikator untuk mengetahui kepadatan nekton di dalam perairan, karena plankton merupakan pakan alami dari ikan. Semakin tinggi kepadatan plankton maka semakin tinggi pula kepadatan nekton di dalam perairan.

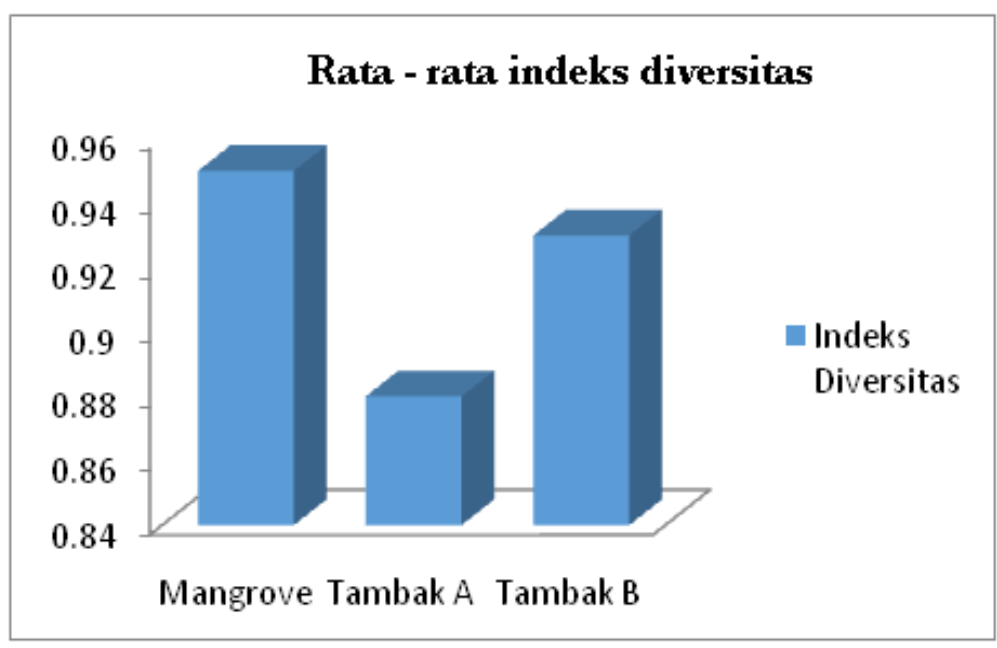

\section{Gambar 9. Grafik indeks diversitas atau keanekaragaman plankton Figure 9. Graph of diversity or diversity index of plankton}

\section{E. Komposisi dan Kerapatan Vegetasi}

Komposisi jenis vegetasi penyusun hutan mangrove yang teridentifikasi pada tambak tahun tanam 1971 ada 3 jenis, yaitu Rhizophora stylosa, Rhizophora mucronata, dan Avicennia marina. Jenis Rhizophora stylosa cukup mendominasi dengan jumlah individu yang paling banyak yaitu 8.096 individu/ha. Jenis
Rhizophora stylosa memiliki pertumbuhan yang cukup baik, dan memiliki daya adaptasi yang cukup tinggi dibanding jenis tanaman mangrove lainnya seperti Rhizophora mucronata, dan Avicennia marina. Jenis Rhizophora stylosa berpotensi untuk dikembangkan sebagai tanaman utama dalam rehabilitasi hutan mangrove.

Tabel 5. Komposisi dan Kerapatan Jenis Penyusun Mangrove

Table 5. Composition and density of type Composer Mangrove

\begin{tabular}{lccc}
\hline \multicolumn{1}{c}{$\begin{array}{c}\text { Jenis } \\
\text { (Species) }\end{array}$} & $\begin{array}{c}\text { Kerapatan Jenis } \\
\text { (Species density) } \\
\text { (ind/ha) }\end{array}$ & $\begin{array}{c}\text { Frekuensi Jenis } \\
\text { (Species frequency) }\end{array}$ & $\begin{array}{c}\text { Indeks Diversitas } \\
\text { (Diversity Index) }\end{array}$ \\
\hline Rhizophora stylosa & 8.096 & 1 & 0,24 \\
Rhizophora mucronata & 560 & 0,17 & 0,52 \\
Avicennia marina & 664 & & 0 \\
\hline
\end{tabular}


Keunggulan lainnya adalah memiliki perakaran yang lebih kompak atau lebih rumit dibandingkan jenis lainnya sehingga fungsi akar sebagai pemecah gelombang akan berfungsi maksimal.

Kerapatan penting untuk diketahui karena merupakan ukuran besar populasi yang berhubungan dengan ruang yang umumnya diteliti dan ditanyakan sebagai cacah individu atau biomassa persatuan luas atau persatuan isi dan seberapa besar peran suatu jenis terhadap lingkungan yang ada (Budiarti, 2007). Indeks diversitas jenis tanaman yang ada kurang dari satu yaitu sebesar 0,24 . Nilai ini menunjukan bahwa indeks diversitasnya rendah, artinya keanekaragaman jenis tanaman mangrove yang ada di lokasi penelitian sangat rendah, hal ini tidak baik untuk peningkatan dan perkembangan biodiversitas. Namun karena fungsi yang diharapkan dari vegetasi mangrove dalam penelitian ini sebagai perlindungan dari gelombang dan pasang surut air laut yang lebih diutamakan, maka nilai indeks diversitas yang rendah dalam pertumbuhan ikan dapat ditoleransi.

\section{F. Lebar Perakaran dan Tinggi Vegetasi}

Tinggi pohon rata-rata selama 36 tahun berdasarkan Tabel 6 sebesar 7,62 m. Pertumbuhan pohon, baik pertumbuhan tinggi maupun hal-hal lainnya yang terkait dengan perkembang biakannya dipengaruhi oleh beberapa faktor yang sangat kompleks. Faktor pembatas seperti temperatur, kandungan zat hara, medium tempat tumbuh, sinar matahari, faktor dari dalam terkait kondisi fisiologis tanaman juga menjadi faktor penentu yang signifikan (Budiarti, 2007). Jadi semakin tinggi suatu vegetasi maka akan semakin lebar perakarannya. Hal ini berguna untuk mengambil unsur-unsur hara di sekitar pohon yang akan digunakan untuk pertumbuhannya.

Pada pada tambak silvofishery lebar akar tanaman sangat berperan dalam menahan arus gelombang air laut. Lebar akar 2,44 meter dan saling bersinggungan antar pohon akan membentuk tanggul dan berfungsi sebagai pemecah ombak. Sehingga bandeng dalam tambak akan hidup dengan tenang dan terlindung dari arus gelombang air laut yang deras.

Tabel 6. Rata-rata lebar perakaran dan tinggi vegetasi tahun tanam 1971

Table 6. Average width and height rooting vegetation planting year 1971

\begin{tabular}{ccc}
\hline $\begin{array}{c}\text { Tahun Tanam } \\
\text { (Year of Planting) }\end{array}$ & $\begin{array}{c}\text { Lebar Akar (meter) } \\
\text { (width Root) }\end{array}$ & $\begin{array}{c}\text { Tinggi Vegetasi (meter) } \\
\text { (high Vegetation) }\end{array}$ \\
\hline 1971 & 2,44 & 7,62 \\
\hline
\end{tabular}

Lebar perakaran suatu tanaman akan mempengaruhi laju aliran air yang melewati tanaman tersebut. Sehingga mempengaruhi banyak sedikitnya seresah atau bahan material yang terangkut (Odum, 1998). Semakin besar lebar perakaran suatu tanaman maka semakin besar pula air, seresah dan bahan materialmaterial yang ada tertahan oleh akar sehingga dapat mempengaruhi laju aliran air yang melewati tanaman tersebut. Jika lebar perakaran suatu tanaman besar maka semakin besar pula air dan seresah yang tertahan oleh akar.

\section{KESIMPULAN DANSARAN}

\section{A. Kesimpulan}

Fungsi hutan mangrove sebagai nursery ground sering dimanfaatkan untuk silvofishery. Tambak A (tahun buat 1960) dan tambak B (tahun buat 1970) dengan perbedaan umur 10 tahun pada tambak silvofishery pola komplangan tidak memberikan perbedaan yang nyata bagi pertambahan berat bandeng. Sehingga umur tambak tidak mempengaruhi pertumbuhan berat bandeng di kedua tambak. Namun sistem silvofishery pola komplangan jauh lebih baik daripada sistem konvensional (tradisonal). 


\section{B.Saran}

Sistem silvofishery pola komplangan dapat meningkatkan pertumbuhan dan produksi bandeng secara langsung, serta dapat menjaga kelestarian hutan mangrove. Karena itu hendaknya petani tambak dapat menerapkan sistem ini secara intensif.

\section{Kelemahan}

Kelemahan penelitian ini yaitu jumlah keramba sebagai plot yang sedikit. Sebaiknya keramba sebagai plot lebih banyak, sehingga akan memperkuat data dan mempermudah dalam analisis. Selain itu untuk bandeng yang digunakan dalam penelitian sebaiknya masih berupa bibit sehingga akan didapatkan data pertambahan berat yang nyata dari awal hingga siap panen (kurang lebih 4 bulan).

\section{DAFTAR PUSTAKA}

Budiarti, A. (2007). Pengaruh Tahun Tanam Mangrove Terhadap Ketebalan Lumpur di Pantai Utara Desa Pasar Banggi Kecamatan Rembang Kabupaten Rembang. Yogyakarta: Fakultas Kehutanan UGM.

Kehutanan, D. (1997). Strategi Nasional Pengelolaan Hutan Mangrove di Indonesia Jilid I. Jakarta: Departemen Kehutanan.

Kusmana, C. (1997). Metode survey vegetasi. Bogor: PT. Penerbit Insitut Pertanian.

Kusmana, C. W. (2003). Teknik Rehabilitasi Mangrove. Bogor: Fakultas Kehutanan IPB.

Kusmana, O. d. (2008). Studi Ekologi Hutan Mangrove di Pantai Timur Sumatera Utara. Biodiversitas, 9, 25-29.

Mahayani, N. P. (2002). Pengaruh Beberapa Pola Silvofishery Terhadap Sifat Fisik Kimia dan Biota Perairan Di Area Mangrove Desa Grinting Kecamatan Bulakamba Kabupaten Brebes. Yogyakarta: Fakultas Kehutanan UGM.

Noor, Y. R. (2006). Panduan Pengenalan Mangrove Di Indonesia. Bogor: Wetlands International Indonesia Programe.

Odum, E. P. (1998). Dasar - dasar Ekologi (Ketiga ed.). (T. Samingan, Trans.) Yogyakarta: Universitas Gadjah Mada Press.

Poedjirahajoe, E. (1998). Pengaruh Pola Silvofishery terhadap Keanekaragaman Biota Laut di Kawasan Mangrove Pantai Utara Kabupaten Brebes. Yogyakarta: Fakultas Kehutanan UGM.

Poedjirahajoe, E. (2005). Upaya Mencari Jarak Tanam Yang Optimal Dalam Rehabilitasi Mangrove Di Pantai Utara Jawa Tengah. Yogyakarta : Fakultas Kehutanan UGM.

Saputra, H. K. (2007). Peranan Mangrove Terhadap peningkatan Produksi Perikanan Tambak Di Kawasan Hutan Mangrove Pantai Utara Kabupaten Rembang Jawa Tengah. Yogyakarta: Fakultas Kehutanan UGM.

Ujang, A. (2002). Pengaruh Hutan Mangrove Terhadap Produktivitas Tambak. Yogyakarta: Fakultas Kehutanan UGM.propinsi Bali. Retrieved January 5, 2012 , f $\mathrm{r}$ o m http:/www.baliprov.go.id/id/Topographi. 